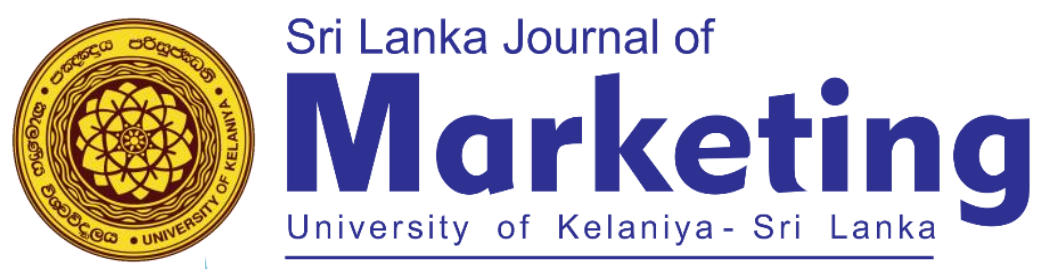

\title{
The Impact of Online Communities and $E$ Word of mouth on Purchase Intention of Generation Y: The Mediating Role of Brand Trust
}

\author{
Kamalasena, B. D. T. M. \\ Assistant Lecturer, University of Ruhuna, Sri Lanka \\ Sirisena, A. B. \\ Senior Lecturer, University of Ruhuna, Sri Lanka \\ amila@badm.ruh.ac.lk
}

\section{ABSTRACT}

Effective marketing and advertising campaigns contribute to customer development, profitability, and business success in the long term. The evolving economies, globalization, and innovative technologies, which have quickly transformed the economic community, make present markets more attractive. Marketing firms are pushed in a new direction by social media marketing, such as Facebook, Twitter, and YouTube. Social media have reached so deeply into millions of people globally and it also has drawn the interest of advertisers. Considering the timeliness and relevance of the phenomenon, this study aims to identify the impact of online communities and e word of mouth on the purchase intention of generation Y. The relevant data were collected through a self-administered questionnaire from 150 individuals aged 25 to 40 years who are residing in the Colombo district based on the convenience sampling method. This study found a positive significant effect of e word of mouth on brand trust and purchase intention and the relationship between e word of mouth and purchase intention is mediate by the brand trust. Further, online communities have a positive significant impact on brand trust and the relationship between online communities and purchase intention is mediated by brand trust. This research fills the gap in the existing literature and provides valuable insights to organizations that use social media marketing as a communication tool.

Keywords: Brand Trust, E Word of Mouth, Online Communities, Purchase Intention, Social Media Marketing 


\section{INTRODUCTION}

Technology plays a significant role in every person's everyday life in this modern world (De Mooij, 2019) and it has significantly influenced every aspect of peoples' lives and it resulted in massive changes in peoples' lifestyles and life patterns. The internet can be identified as one of the crucial parts of Technology that also has changed the world dramatically. The Internet is responsible for offering individuals, businesses, and others a place to communicate and various companies may advertise their products or services to increase their share of the market (Chaffey \& Ellis-Chadwick, 2019). In addition to that consumers are using it for many reasons, including gathering online shopping information. It is said that buying through the internet is way more efficient (Manzoor, Baig, Hashim, \& Sami, 2020).

When considering technology and the internet, social media is one of the key aspects that cannot be ignored. Social media growth is an impressive marketing tool for companies. Moreover, according to Irfan, Rasli, Sulaiman, Sami, \& Qureshi, (2019) social media is an effective tool for economic growth as they provide two-way communication and low-cost marketing to obtain information, connect and establishment of relationships with their customers. The invention of the social media network has had a significant effect on business practices and has changed marketing strategies drastically (Irfan, Rasli, Sulaiman, Sami, \& Qureshi, 2019). Social media has increasingly become one of the most influential youth networks today. As per Kaplan \& Haenlein (2010) the use of social media is continuously increasing among Generation Y or "Boomerang Kids". As per Werenowska \& Rzepka (2020) without technical innovations, a generation born after 1980 cannot imagine a world. Social media are an indicator of their existence. You may say that someone without a Facebook account is "not exist" and is not even exempt from social circles. Social media marketing is the newest marketing trend and business owners want to learn how to create their businesses' interest. Social media plays a very significant role in the decision-making process of consumers. Platforms such as Facebook, LinkedIn, YouTube, and Twitter have enabled customers' access to product reviews and other similar people in their communities.

People reach their social media communities for their opinions before they make shopping today (Hajli, 2015). Consumers use social media to access online groups, to get others' reviews, and to get a better understanding of a product or service (Dedeoglu, Taheri, Okumus, \& Gannon, 2020). Social media is becoming more important in the fields of marketing, advertising, and communication with an annual rise in the number of users (Appel, Grewal, Hadi, \& Stephen, 2020). Customers with a close relationship with a company share their social media experiences with other people and propose their company's products or services to their mates through positive words of mouth (Manzoor, Baig, Hashim, \& Sami, 2020). Social media, therefore, becomes a priority for market intelligence, because advertisers understand the buying behavior of customers and understand why consumers feel as they do about those products (Rockendorf, 2011). These opportunities allow the marketer to build a dialog with the 
customer and to refine the message and maintain the brand online marketing platforms (Evans \& McKee, 2010).

Even though there is a continuous growth in social media development and usage the academic attention to understand the prospective context falls behind the industry. Some researchers have identified that still there is a gap in the existing literature (e.g.: Ebrahim, 2019; Manzoor, Baig, Hashim, \& Sami, 2020). In addition to these research studies, local studies also have highlighted the existing research gap in social medial marketing (e.g: Perera \& Udunuwara, 2021). Considering the timeliness and importance of the phenomenon and practical and theoretical gaps that exist, this study is focused on identifying the impact of online communities and $\mathrm{E}$ word of mouth on consumer purchase intention. Accordingly, the research objectives are formed as, to examine the impact of E- word-of-mouth on consumer purchase intention, impact of online communities on consumer purchase intention, mediating effect of brand trust on the relationship between E word of mouth and purchase intention, and the mediating effect of brand trust on the relationship between online communities and purchase intention.

\section{LITERATURE REVIEW}

\subsection{Social Media}

According to Kaplan \& Haenlein (2010), in 1979 the worldwide discussion system of Usenet was founded by Tom Truscott and Jim Ellis, from the University of Duke, which allowed internet users to post public messages. However, the era of social media as we understand it today probably began around twenty years previously, when Bruce and Susan Abelson created "Open diary" an early website for networking, where writers were brought together in one group. The word "Weblog" was first used concurrently and was truncated one year later as a "blog" when a blogger jokingly modified the noun "weblog" into a "we-blog" sentence (Kaplan \& Haenlein, 2009b). High-speed internet access is increasingly widespread, leading to the establishment of social networking websites, such as MySpace in 2003 and Facebook in 2004. This coined the word "Social media" and contributed to its popularity today (Kaplan \& Haenlein, 2009a). Social media can be defined as a digital-based software set, which is typically presented as applications and websites, and users can use it for sending or receiving digital content or information through an online social network. Social media is the leading platform with its features, including Facebook, Instagram, Twitter, and so on (Appel, Grewal, Hadi, \& Stephen, 2020).

\subsection{Social Media Marketing}

As per Larimo \& Leonidou (2021, p.54) SMM can be defined as “an organization's integrated pattern of activities that, based on a careful assessment of customers' motivations for brand-related social media use and the undertaking of deliberate engagement initiatives, transform social media connectedness (networks) and interactions (influences) into valuable strategic means to achieve desirable marketing 
outcomes". Conventional media like newspapers and TV programs are still common and feasible mediums for advertising and make influence consumer behavior. Though, social media is becoming more dominant for companies because it allows ongoing and worldwide conversations. Consumers and businesses are more informed with real-time information and continuous social feedback, making informed decisions and fewer mistakes in their decisions through social media (Appel, Grewal, Hadi, $\&$ Stephen, 2020).

\subsection{Generation $Y$}

Those of Generation Y are also referred to as 'millennials,' which means that people born in 1980-2000 Werenowska \& Rzepka (2020). According to Main (2017) Generation Y is characterized by its openness to new ideas and ways of living and their confidence. This cohort's priorities differ from other cohorts, in that the Y-generation values convenience and focuses more on experiences rather than on products (Parets, 2019). In addition, individuals from Generation $Y$ are known to have spent more time online than other cohorts. Generation Y individuals nevertheless balance real life with the online world as they came into the technological age (Thompson, 2018). According to Schawbel (2015), More than half the consumer of Y generation describes themselves as loyal to the brand and will repurchase the same product once they trust. However, before purchasing a decision or trusting a business, product, or service, Y consumers actively seek information (Jorg, 2017).

\subsection{E Word of Mouth}

Word of mouth provides customers with marketing information to the degree that it impacts their attitudes and behavior in respect of a product or service (Huete-Alcocer, 2017). E-WOM costs of informal Internet communication aimed at consumers and related to the usability or key properties of a product or service, or the brand that stands behind it. Furthermore, Huete-Alcocer (2017) stressed that the advantage of this tool is that each customer can take part, as everyone can share an online experience and post a product review for other users to read. The intensity of e word of mouth has also increased exponentially as social media and digital platforms grow (Al-Gasawneh \& Al-Adamat, 2020). E word of mouth messages are easily exchanged among Internet users and are delivered in the form of online notifications, reviews, and recommendations and sources provide information about a product or service to present, past, and potential customers. This also provides businesses with the benefits of facilitating customer identification and also it is an affordable way for potential customers to connect (AlGasawneh \& Al-Adamat, 2020).

\subsection{Online Communities}

According to Ray, Kim, \& Morris (2014), online communities are new social structures that rely on modern information technology to function, and they face similar modern challenges. People of all ages 
have turned to online communities for a variety of reasons, including discussing topics that are important to them, sharing knowledge, and reviewing products and services to educate and assist others (Kuem, Khansa, \& Kim, 2020). Simmons (2008) argues that online communities function as virtual glues to quench customer desire to become part of a community. The information repositories of online communities must be fed with reliable and up-to-date information regularly; otherwise, their members' value will continue to shrink. As a consequence, the value of an online community is determined by the contributions of its members (Johnson, Faraj \& Kudaravalli, 2014; Phua, Jin \& Kim, 2017).

\subsection{Consumer Purchase Intention}

According to Oosthuizen, Spowart, \& Meyer-Heydenrych (2015) purchasing intentions are based on behavioral science. The purchasing intention of consumers is defined as a combination of their interests and their willingness to buy a product. Purchase intentions are an attitudinal variable that can be used to estimate future contributions to product purchases. Since predicting future consumer behavior is a crucial problem for businesses, it should be estimated more specifically (Baabdullah, Alalwan, Rana, Kizgin, \& Patil, 2019). The formation of a consumer's purchase intentions is influenced by their general attitudes toward a product (Cheruiyot \& Maru, 2013). The more positive these attitudes are, the more likely people are to purchase (Manzoor, Baig, Hashim, \& Sami, 2020). A similar definition was proposed by (Beneke, Flynn, Greig, \& Mukaiwa, 2013; Faryabi, Fesaghandis, \& Saed, 2015; Wu, 2015), all of whom focused on the willingness of consumers to purchase a specific product.

\subsection{Brand Trust}

Trust is defined as the customer believes that certain brands can fulfill needs and desires so that when clients have trust in the product, a repeated buying behaving is created, leading to brand engagement and establishing a relationship between brand and customer (Chinomona \& Maziriri, 2017). According to Mckinney \& Benson, (2013) from a market point of view, trust is defined as a consumer willingness to return to a brand. Cakmak (2016) identifies brand trust as the consumer's intention toward the brand, taking account of consumer benefits and solutions, and the ability, capacity and needs to obtain the desires and needs of consumers. Chaudhuri \& Holbrook (2001) believe that brand trust involves a carefully designed and carefully considered process. Kim, Kim, \& Lee (2019) describes brand trust as a key factor to define the attitude of an individual in a company relationship. Managers must therefore see it as a key to business success. 


\section{HYPOTHESIS DEVELOPMENT}

\subsection{E Word of Mouth and Purchase Intention}

Because of the vast changes in technology and the widespread use of the internet, which allows consumers to exchange consumption-related advice by engaging in online activities, the way consumers communicate with one another has changed dramatically. As a result of the internet, a less intimate but universal mode of communication known as electronic word of mouth has arisen (Brown, Broderick, \& Lee, 2007; Xia \& Bechwati, 2008). Studies have shown that when customers gather pre-purchase information (Zhu \& Zhang, 2010; Adjei, Noble, \& Noble, 2009), they are increasingly likely to accept online product feedback, which differs not just in quality but also in polarity from positive to negative comments (Sparks \& Browning, 2011). Ladhari \& Michaud (2015) identified that positive online comments about a particular hotel resulted in a significantly higher booking intention for it. In addition to that, Al-Debei, Akroush, \& Ashouri (2015) mentioned that EWOM evaluations may all affect customer outlooks, opinions, purchase decisions, and post-use evaluations. Moreover, Elseidi \& El-Baz (2016) also identified that e word of mouth has a significant impact on purchase intention. Therefore, it is hypothesized that $\mathrm{E}$ word of mouth has a significant positive impact on consumer purchase intention among the $\mathrm{Y}$ generation.

H1: E word of mouth has a significant positive impact on consumer purchase intention

\subsection{Online Communities and Purchase Intention}

The advent of these online communities offers forums for online customers to share and exchange ideas, viewpoints, and product/service-related data. This creates tremendous opportunities for retailers, especially those who operate online. Accordingly, (Balakrishnan, Dahnil \& Yi, 2012) identified that online communities have a significant impact on the purchase intention of consumers. Moreover, the lack of workable rules in online communities increases the value of trust (Ridings, Gefen, \& Arinze, 2002). In addition to that, compared to conventional advertising components, customers consider social media as more trustworthy (Foux, 2006). It could be because social media provides interactive communication, provides direct feedback, and produces more objective content (Tatar \& ErenErdoğmuş, 2016). Consequently, this study also hypothesized that online communities have a positive significant impact on purchase intention among Generation Y.

H2: Online communities have a significant positive impact on consumer purchase intention

\subsection{Mediating effect of Brand Trust}

A great deal of research support that brand trust mediates the relationship between e word of mouth and purchase intention. For an instance, Liao \& Chung (2019) and Bhandari \& Rodgers (2018) discovered that brand trust mediates the relationship between $\mathrm{E}$ word of mouth and purchase intention. However, 
in social media literature the there is little emphasis on this mediating effect especially, regarding Generation Y. Considering the findings of the prior studies, this study hypothesized,

H5: The relationship between $\mathrm{E}$ word of mouth and purchase intention is mediated by brand trust

H6: The relationship between online communities and purchase intention is mediated by brand trust

The following conceptual framework explains the study further and is also used to test the stated hypotheses of the study.

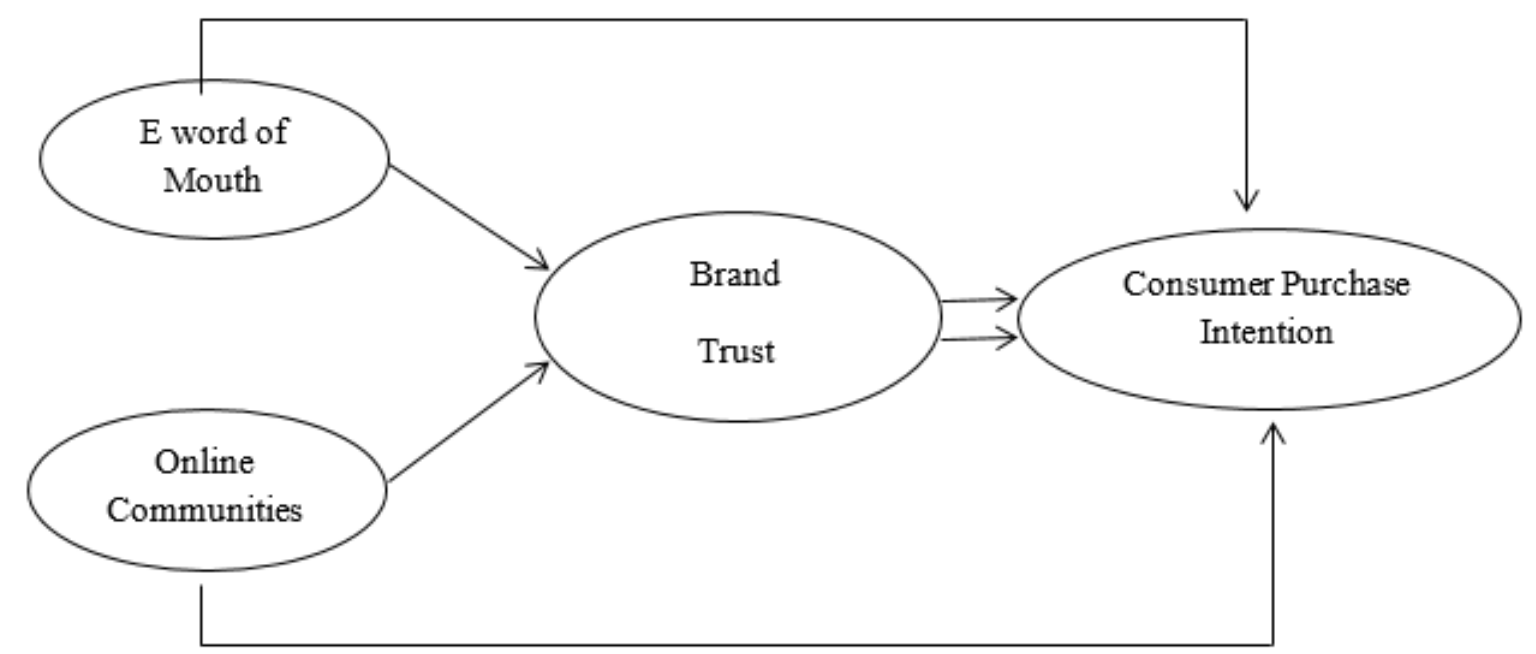

Figure 1: Conceptual Framework

\subsection{Operationalization of Variables}

\begin{tabular}{|l|l|l|}
\hline Variable & Scale items & Source \\
\hline E- Word of Mouth & $\begin{array}{l}\text { EWOM1. I will go through the online } \\
\text { information shared by people before making a } \\
\text { purchase. }\end{array}$ & $\begin{array}{l}\text { (Anusha, Poojitha, \& Podile, } \\
\text { EWOM2. I will seek the advice of people } \\
\text { through online } \\
\text { EWOM3. I trust other people's opinion which } \\
\text { was shared online } \\
\text { EWOM4. I like to gather the opinions of others } \\
\text { through online before I buy a product } \\
\text { EWOM5. Online opinions of others will not } \\
\text { trigger me while I'm choosing a product }\end{array}$ \\
\hline Online Communities & $\begin{array}{l}\text { OC1. I will be discussing with my online } \\
\text { community while buying a product } \\
\text { OC2. I will have a conversation with my online } \\
\text { community about buying a product that we see } \\
\text { or heard through advertisements. } \\
\text { OC3. I will have trust in my online community } \\
\text { opinion } \\
\text { OC4. My online communities ask for my } \\
\text { advice regarding the product which they buy. }\end{array}$ & \\
\hline
\end{tabular}




\begin{tabular}{|l|l|l|}
\hline Purchase Intention & $\begin{array}{l}\text { PI1. I think shopping on the internet saves my } \\
\text { time. }\end{array}$ & $\begin{array}{l}\text { (Manzoor, Baig, Hashim, \& } \\
\text { SI2. It is a great advantage for me to buy } \\
\text { products at any time of the day } \\
\text { PI3. Online shopping is as secure as traditional } \\
\text { shopping } \\
\text { PI4. The information given about the products } \\
\text { and services on the internet is sufficient }\end{array}$ \\
\hline Brand Trust & $\begin{array}{l}\text { BT1. My brand gives me everything that I } \\
\text { expect out of the product } \\
\text { BT2. I rely on my brand } \\
\text { BT3. My brand never disappoints me }\end{array}$ & (Sohail \& Hasan, 2020) \\
\hline
\end{tabular}

\section{METHODOLOGY}

This research study followed a quantitative research approach and the research design is single crosssectional. Necessary data was collected through a self-administered questionnaire from individuals who are between the ages of 25 years to 40 years using social media in the Colombo district. Consequently, the sample consisted of 150 individuals who are chosen through the non-probabilistic convenience sampling method.

The study emphasized on Generation Y who are in the age of 25 years to 40 years is as Kaplan \& Haenlein (2010) outlined social media is continuously increasing among Generation Y or "Boomerang Kids". Moreover, according to Prensky(2001) members of Generation Y are referred to as "digital natives" rather than digital immigrants. They are the first generation to have grown up in a digital world, and information technology has had a huge influence on how they live and work (Bennett, Maton, \& Kervin, 2008). In addition to that, the sample of the study was based on the Colombo district as it consists of the highest population and highest population density in Sri Lanka (Department of Census and Statistics, 2021). The sample size of the study was determined as per the guidelines of Krejcir \& Morgan (1970). The researcher collected data based on the non-probabilistic convenience sampling method as participates of the sample are easily accessible to the researcher and this method is common because it can assess a large number of survey participants in a short period (Etikan, Musa, \& Alkassim, 2016). Similar studies such as (Balakrishnan, Dahnil \& Yi, 2012; Manzoor, Baig, Hashim \& Sami, 2020) have employed convenience sampling as the sampling technique.

The research study was carried out in three steps. First of all, a literature survey was carried out to gather extensive information on the subject of study. Constructs have been operationalized by a thorough analysis of the literature (Manzoor, Baig, Hashim, \& Sami, 2020; Hanaysha, 2016) and calculated in a 5 -point Likert scale ranging from $1=$ strong disagree to $5=$ strongly agree. Second, there have been few expert reviews to guarantee the questionnaire's accuracy and applicability. Next, a pilot study of 20 
respondents was carried out and the final questionnaire required adjustments were made based on the findings. Finally, there was a field study for data collection.

The developed questionnaire consisted of filter questions to select the most appropriate individuals for the sample group. Furthermore, the questionnaire consisted of two parts. First, the socio-demographic questions were included to determine the sample profile and the next part evaluated the e- word-ofmouth, online communities, consumer purchase intention, and brand trust.

\subsection{Data Presentation and Analysis}

Collected data were screened to identify the missing values and outliers. As the questionnaire was improved based on the findings of expert feedback and pilot tests, it makes it easier for the respondents to respond to the questionnaire, and therefore, there were very few missing values in the data set. Those missing values have been replaced by the median (Little \& Rubin, 2002). Box plots were used to determine the existence of outliers (Aguinis, Gottfredson \& Joo , 2013) and the seven cases were as outliers and were removed from the database.

In addition, factor analysis was performed to assess the uni-dimensionality of the constructs. All factor loadings were significant and were shown above 0.6 as recommended by (Hair, Black, Babin \& Anderson, 2010) . Afterward, the Normality of the data was tested using Skewness and Kurtosis values and according to the standard Skewness and Kurtosis values should be in between +2 and -2 for the data to be normally distributed. Accordingly, the Skewness and Kurtosis values are shown in Table 1.

Table 1: Results of Test of Normality

\begin{tabular}{lcccc}
\hline & \multicolumn{2}{c}{ Skewness } & \multicolumn{2}{c}{ Kurtosis } \\
\hline & Statistic & Std. Error & Statistic & Std. Error \\
E Word of Mouth & -0.409 & 0.198 & -0.695 & 0.394 \\
Online Communities & -0.395 & 0.198 & -0.555 & 0.394 \\
Consumer Purchase Intention & -0.805 & 0.198 & 0.075 & 0.394 \\
Brand Trust & -0.357 & 0.198 & -0.708 & 0.394 \\
\hline
\end{tabular}

Source: Survey Data, 2020

The convergent validity of the data was tested using AVE value and CR values. As per the standard AVE values should be greater than 0.5 and CR values should be greater than 0.7 . The outcomes of the convergent validity test were within the standard values ensuring the convergent validity of the data. Table 2 shows the results of convergent validity. 
Table 2: Results of Convergent Validity Test

\begin{tabular}{lll}
\hline \multicolumn{1}{c}{ Variable } & AVE & CR \\
\hline E Word of Mouth & 0.563 & 0.837 \\
Online Communities & 0.700 & 0.874 \\
Consumer Purchase Intention & 0.609 & 0.757 \\
Brand Trust & 0.500 & 0.749 \\
\hline
\end{tabular}

Source: Survey Data, 2020

According to Hair, Black, Babin, \& Anderson, (2010), discriminant validity indicates the extent to which a construct is distinct from other constructs. Consequently, to ensure the discriminant validity, all construct average variance extracted (AVE) estimates should be greater than the corresponding "squared inter-construct correlation estimates (SIC)". When considering the reliability of the data, Cronbach's Alpha values were used to test the internal consistency of the data. According to the standard Cronbach's Alpha value should be higher than 0.07 The results of the discriminant validity and reliability tests were depicted in tables 3 .

Table 3: Results of Discriminant Validity and Reliability Tests

\begin{tabular}{|c|c|c|c|c|c|}
\hline & $\begin{array}{c}\text { E Word of } \\
\text { Mouth }\end{array}$ & $\begin{array}{c}\text { Online } \\
\text { Communities }\end{array}$ & $\begin{array}{l}\text { Purchase } \\
\text { Intention }\end{array}$ & Brand Trust & $\begin{array}{l}\text { Cronbach's } \\
\text { Alpha Value }\end{array}$ \\
\hline $\begin{array}{l}\text { E Word of } \\
\text { Mouth }\end{array}$ & 0.836 & & & & 0.864 \\
\hline $\begin{array}{c}\text { Online } \\
\text { Communities }\end{array}$ & 0.534 & 0.750 & & & 0.911 \\
\hline $\begin{array}{l}\text { Purchase } \\
\text { Intention }\end{array}$ & 0.592 & 0.434 & 0.780 & & 0.898 \\
\hline Brand Trust & 0.606 & 0.651 & 0.650 & 0.707 & 0.832 \\
\hline
\end{tabular}

\subsection{Sample Profile of the Study}

The sample of the study is individuals aged 25 years to 40 years who are currently using social media platforms in Colombo district, Sri Lanka. In the sample. the majority are males (59.3\%) who are engaging in managerial level jobs (32.0\%). In addition to that, the majority of the sample is using Facebook, Whatsapp, and Instagram (36.7\%) who purchase apparel (30.0\%) through social media.

Table 4: Sample profile of the study

\begin{tabular}{llll}
\hline & & Frequency & Percentage \\
\hline \multirow{3}{*}{ Gender } & Male & 89 & 59.3 \\
& Female & 61 & 40.7 \\
& Total & 150 & 100.0 \\
\hline Occupation & Managerial Level & 48 & 32.0 \\
& Self-employed & 37 & 24.7 \\
& Trainee/intern & 24 & 16.0 \\
\hline & Facebook, Instagram & 32 & 21.3
\end{tabular}




\begin{tabular}{|c|c|c|c|}
\hline \multirow[t]{2}{*}{$\begin{array}{l}\text { Currently using Social } \\
\text { Media Platforms }\end{array}$} & $\begin{array}{l}\text { Facebook, Instagram, } \\
\text { Whatsapp }\end{array}$ & 55 & 36.7 \\
\hline & Facebook, Whatsapp & 27 & 18.0 \\
\hline & Accessories & 29 & 19.3 \\
\hline Products & apparels & 45 & 30.0 \\
\hline through social media & $\begin{array}{l}\text { Beauty and Personal care } \\
\text { products }\end{array}$ & 34 & 22.7 \\
\hline
\end{tabular}

Source: Survey Data, 2020

\subsection{Correlation coefficients among variables}

Table 5: Correlation coefficients

\begin{tabular}{|c|c|c|c|c|}
\hline & $\begin{array}{c}\text { E Word of } \\
\text { Mouth }\end{array}$ & Online communities & Brand Trust & VIF \\
\hline E word of Mouth & 1 & & & 1.832 \\
\hline Online communities & 0.534 & 1 & & 1.669 \\
\hline Brand Trust & 0.606 & 0.651 & 1 & 2.068 \\
\hline Purchase Intention & 0.592 & 0.434 & 0.650 & \\
\hline
\end{tabular}

Source: Survey Data, 2020

The correlation among variables is summarized in table 5. Accordingly, there are positive relationships across all variables and all values are significant at 0.99 level. The highest correlation among variables is 0.650 at a $99 \%$ confidence level, which shows between brand trust (mediating variable) and purchase intention (dependent variable). Furthermore, the highest VIF value is 2.068 , which is below the standard level of 10 (Hair, Sarstedt, Ringle \& Mena, 2012) which guarantees the absence of multicollinearity issues.

\subsection{Mediation Analysis using PROCESS Macro}

The hypothesized model was tested using bootstrap-based Hayes' PROCESS macro (Hayes, 2013). The PROCESS macro is a well-known 'statistical resampling technique that estimates the model's parameters and standard errors strictly from the sample. As compared to Baron and Kenny's (1986) causal step approach, this technique measures precise and correct confidence intervals for indirect effects.

Table 6: Regression results for simple mediation ( $E$ word of mouth as a predictor)

\begin{tabular}{lcccc}
\hline Predictor & $\boldsymbol{\beta}$ & SE & t value & p-value \\
\hline Brand Trust (M) & & & & \\
Constant & 0.9548 & 0.3032 & 3.1484 & 0.002 \\
EWOM (X) & 0.7035 & 0.0759 & 9.2623 & 0.000 \\
\hline Model Summary & $\mathrm{R}$ & $\mathrm{R}^{2}$ & $\mathrm{p}$-value & \\
& 0.6058 & 0.3670 & 0.000 & 0.014 \\
\hline Purchase Intention (Y) & & & & 2.4850 \\
Constant & 0.7336 & 0.2952 & 4.2181 & 0.000 \\
EWOM (X) & 0.3794 & 0.0900 & 6.1790 & 0.000 \\
Brand Trust (M) & 0.4786 & 0.0775 & & \\
\hline
\end{tabular}




\begin{tabular}{lcccc}
\hline Model Summary & $\mathrm{R}$ & \multicolumn{2}{c}{$\mathrm{R}^{2}$} & $\mathrm{p}$-value \\
& 0.6962 & 0.4848 & 0.000 \\
\hline Indirect Effect of EWOM (X) on Purchase Intention (Y) & & \\
& Effect & BootSE & BootLLCI & BootULCI \\
Brand Trust (M) & 0.3367 & 0.0775 & 0.1968 & 0.5025 \\
\hline Source: Survey Data, 2020 & & &
\end{tabular}

Table 6 illustrates that $E$ word of mouth positively impacts brand trust $(\beta=0.7035, t=9.2623, p=0.00)$. The $\mathrm{R}^{2}$ of the model shows a value of 0.3670 , which indicates that $36 \%$ of the variation of the brand trust is explained by $\mathrm{E}$ word of mouth. Besides, brand trust positively impacts purchase intention ( $\beta=$ $0.4786, \mathrm{t}=6.1790, \mathrm{p}=0.00$ ) and $\mathrm{E}$ word of mouth positively impacts on purchase intention and purchase intention $(\beta=0.3794, t=4.2181, p=0.00)$. Considering the $R^{2}$ value it can conclude that $48 \%$ of the variance of the purchase intention is explained by $E$ word of mouth and brand trust $\left(\mathrm{R}^{2=} 0.4848\right)$. The indirect effect of $\mathrm{E}$ word of mouth on purchase intention is significant and positive since the resulting confidence interval of bootstrapping does not include zero ( $\mathrm{CI}=0.1968,0.5025)$, which indicates that brand trust mediates the relationship between $\mathrm{E}$ word of mouth and purchase intention.

Table 7: Regression results for simple mediation (online communities as a predictor)

\begin{tabular}{|c|c|c|c|c|}
\hline Predictor & B & SE & t value & p-value \\
\hline \multicolumn{5}{|l|}{ Brand Trust (M) } \\
\hline Constant & 1.7825 & 0.1933 & 9.2223 & 0.000 \\
\hline Online Communities $(\mathrm{X})$ & 0.5654 & 0.0543 & 10.4199 & 0.000 \\
\hline \multirow[t]{2}{*}{ Model Summary } & $\mathrm{R}$ & $\mathrm{R}^{2}$ & p-value & \\
\hline & 0.6505 & 0.4232 & 0.000 & \\
\hline \multicolumn{5}{|l|}{ Purchase Intention (Y) } \\
\hline Constant & 1.4743 & 0.2535 & 5.8166 & 0.000 \\
\hline Online Communities (X) & 0.0181 & 0.0747 & 0.2423 & 0.808 \\
\hline Brand Trust (M) & 0.6630 & 0.0859 & 7.7184 & 0.000 \\
\hline \multirow[t]{2}{*}{ Model Summary } & $\mathrm{R}$ & $\mathrm{R}^{2}$ & p-value & \\
\hline & 0.6501 & 0.4226 & 0.000 & \\
\hline \multicolumn{5}{|c|}{ Indirect Effect of Online Communities (X) on Purchase Intention (Y) } \\
\hline & Effect & BootSE & BootLLCI & BootULCI \\
\hline Brand Trust (M) & 0.3749 & 0.0747 & 0.2463 & 0.5291 \\
\hline
\end{tabular}

According to Table 5, online communities have a positive impact on brand trust $(\beta=0.5654, t=10.4199$, $\mathrm{p}=0.000$ ). The $\mathrm{R}^{2}$ of the model shows a value of 0.4232 , which indicates that $42 \%$ of the variation of brand trust is explained by online communities. When considering about online communities and purchase intention, it shows an insignificant impact $(\beta=0.0181, \mathrm{t}=0.2423, \mathrm{p}=0.808)$. Besides, brand trust positively impacts purchase intention $(\beta=0.6630, t=7.7184, p=0.000)$. Considering the $\mathrm{R}^{2}$ value of the model, it can conclude that $42 \%$ of the variance of the purchase intention is explained by online communities and brand trust $\left(\mathrm{R}^{2=} 0.4226\right)$. 
The indirect effect of online communities on purchase intention is significant and positive since the resulting confidence interval of bootstrapping does not include zero $(\mathrm{CI}=0.2463,0.5291)$, which indicates that brand trust mediates the relationship between online communities and purchase intention.

\section{DISCUSSION AND CONCLUSION}

Among the advanced technologies exists the Internet and social media are key aspects that cannot be ignored. Considering social media networks, it has affected business practices and also changed marketing strategies drastically (Irfan, Rasli, Sulaiman, Sami \& Qureshi, 2019). Moreover, social media can be identified as an effective communication tool that provides two-way communication and lowcost marketing to obtain information, connect, and establishment of relationships with their customers. Among Generation Y or "Boomerang Kids" the use of social media is continuously increasing (Kaplan $\&$ Haenlein, 2010). People tend to reach online communities to get a thorough understanding from the reviews of other people about the product or service that they are going to purchase. Customers who have a good prior experience with a brand or product, tend to recommend those products to others through positive word of mouth. Therefore, social media becomes the main concern in market intelligence, as marketers have the opportunity to understand consumer behavior, and through is understanding, marketers can redefine their communication strategies to build up long-term relationships with their customers. Accordingly, the main aim of this research study is to "identify the impact of online communities and e word of mouth is social media on purchase intention of generation with the mediating effect of brand trust". The summary of the results obtained through the analysis is shown in table 8 and figure 2.

Table 8: Summary of Hypotheses testing

\begin{tabular}{|c|c|c|}
\hline Hypothesis & & Survey findings \\
\hline H1 & $\begin{array}{l}\text { E word of mouth has a significant positive impact on consumer } \\
\text { purchase intention }\end{array}$ & Supported \\
\hline $\mathrm{H} 2$ & $\begin{array}{l}\text { Online communities have a significant positive impact on consumer } \\
\text { purchase intention }\end{array}$ & Rejected \\
\hline H3 & $\begin{array}{l}\text { The relationship between } \mathrm{E} \text { word of mouth and purchase intention } \\
\text { is mediated by brand trust }\end{array}$ & Supported \\
\hline $\mathrm{H} 4$ & $\begin{array}{l}\text { The relationship between online communities and purchase } \\
\text { intention is mediated by brand trust }\end{array}$ & Supported \\
\hline
\end{tabular}


Figure 2: The Summary of PROCESS Macro Results

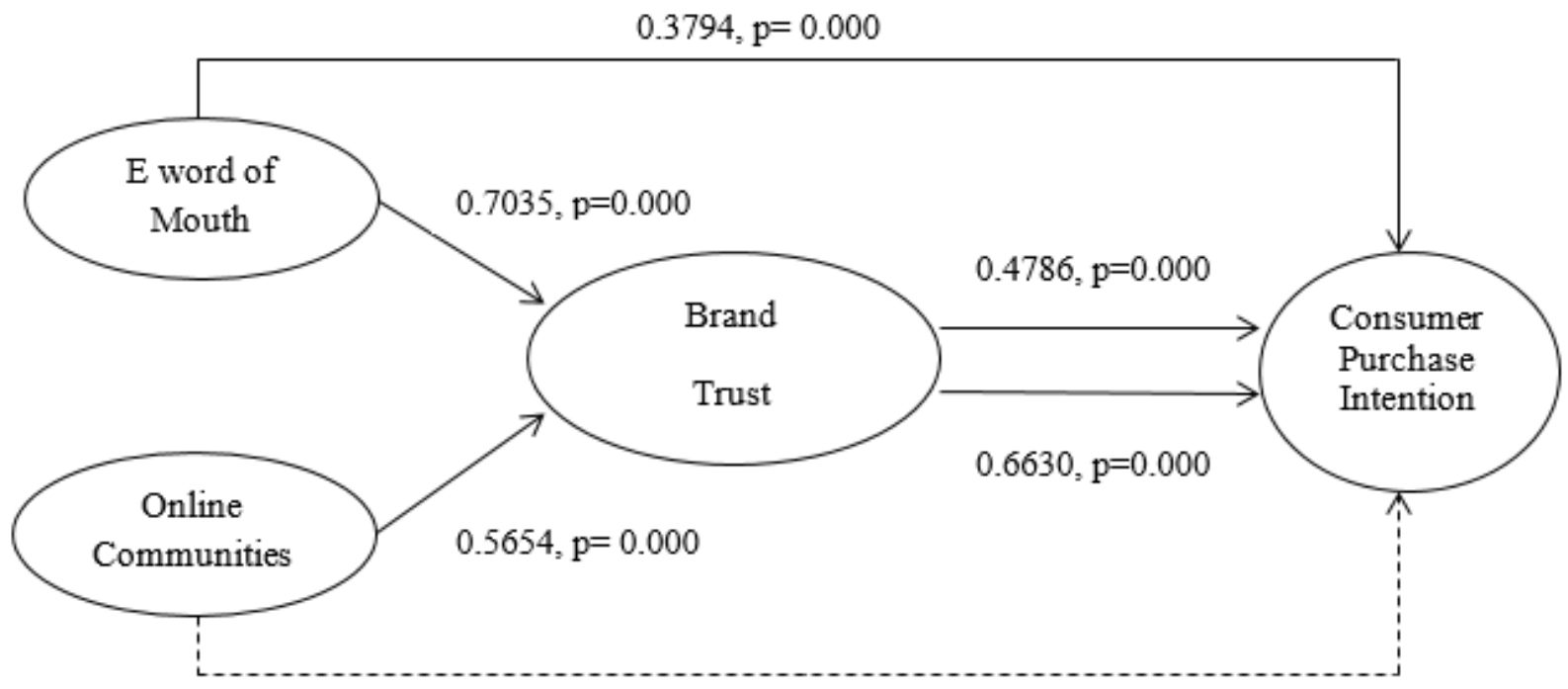

$0.0181, p=0.808$

Source: Compiled by Author

The results from the study show that E word of mouth has a significant positive impact on purchase intention as well as on brand trust. Moreover, brand trust mediates the relationship between e word of mouth and consumer purchase intention. On the other hand, online communities have a significant positive impact on brand trust but, it shows an insignificant impact on the purchase intention while brand trust mediated the relationship between online communities and purchase intention. It can conclude that online communities do not directly impact purchase intention, but if brand trust is created through online communities then consumers tend to purchase a particular product or service.

When considering the prior literature, similar results were found in different products and service contexts. Referring to the automobile industry, Jalilvand \& Samiei, (2012) have identified that e word of mouth has a strong positive impact on consumer purchase intention. Moreover, they have mentioned that both practical experiences and previous studies revealed that customers are increasingly keen to write and to read positive and negative experiences in an online WOM context. In addition to that when considering about travel and hospitality industry, Jalilvand \& Samiei, (2012) has also identified that e word of mouth plays a crucial role in increasing tourists' travel intentions, creating a favorable destination image, and reducing promotional expenditure. Mehyar, Saeed \& Baroom, (2020) also proved the positive impact of e word of mouth on consumer purchase intention and stressed that the ease of understanding message (reviews/comments) (EWOM quality) and the amount of message through social websites (EWOM quantity) will be able to influence on the purchasing intention of prospects customers. When considering the impact of e word of mouth on brand trust, the results indicate a positive significant impact and this is further proved by Renteria-García, Fajardo-Toro \& Sabogal-Salamanca, (2021). They further mentioned that consumers have more resources to get information about the product or service when considering a purchase online than those offered by the 
retailer or manufacturer. These new resources are generated by customers and therefore are more trustworthy to consumers who suggest purchasing a product.

As per the findings of the study, the relationship between e word of mouth and purchase is mediated by brand trust. This finding is further proved by (Liao \& Chung, 2019). In their research study, they found that word of mouth is positively related to purchase intention and brand trust. Moreover, they found brand trust mediated the relationship between word of mouth and purchase intention. Bhandari \& Rodgers, (2018) have also identified that the relationship between E word of mouth and purchase intention is mediated by brand trust.

This study indicates that online communities are positively related to brand trust. Jung, Kim \& Kim, (2014) and Ulusu, Erdem \& Durmuş, (2016) also identified the positive impact of online communities on brand trust. Furthermore, this study resulted in an insignificant impact on online communities and purchase intention. But, Balakrishnan, Dahnil \& Yi, (2012) have identified a positive effect of online communities on purchase intention. Moreover, as per the findings of this study, even though online communities are not directly affected by purchase intention, online communities have an indirect effect on purchase intention. From a practical stance, it could be argued that the reviews, comments, and interactions within an online community which are capable to create brand trust subsequently affect purchase intention.

\section{IMPLICATIONS OF THE STUDY}

Even though social media marketing plays a vital role at present, the number of prior studies conducted on identifying the impact of e word of mouth and online communities on purchase intention with the mediating effect of brand trust in generation $\mathrm{Y}$ is very low. Therefore, this study provides valuable insights into the development of both theoretical and managerial aspects of the social media marketing sector. As mentioned above, the scholarly attention given to understanding the factors affecting purchase intention in social media marketing among generation $\mathrm{Y}$ is very low in both local and global contexts. Therefore, this study fills the gap in the existing literature by adding knowledge on E-word of mouth, online communities, purchase intention, and brand trust, particularly on generation Y.

As managerial implications, this study provides valuable insights to marketers who are using social media as a communication platform. When they are creating brands or online communities they should concentrate on factors that create brand trust among the customers which ultimately drives to create purchase intention. Moreover, as e word of mouth has a significant effect on purchase intention and brand trust if there is a possibility of spreading negative e word of mouth, it will badly affect brand trust and purchase intention. Therefore, organizations should take necessary steps to manage the spread of negative e word of mouth. Most importantly, when organizations are offering their products and services to the customers they should highly concern about the quality of the products and services 
because with the development of social media even a small mistake of the organization can be spread viral and can adversely affect the brand trust and purchase intention.

\section{LIMITATIONS AND FUTURE RESEARCH SUGGESTIONS}

This research study contains several limitations. Firstly, when considering the sample of 150 respondents who are residing in the Colombo district is a significant limitation of the study. Next, as this study is limited to a quantitative approach, the research was unable to explore some of the important insights from the respondents. Therefore, as future research suggestions, we can recommend following a qualitative approach which will provide an opportunity to explore valuable responses from the sample. Moreover, this study can be extended geographically to other districts of Sri Lanka or can be conducted as a comparative study comparing two geographic areas.

In addition to that this study only takes into account brand trust as a mediating variable and purchase intention as the dependent variable. Future research studies can be done incorporating variables such as brand image, customer revisit intention, and so on as mediating variables and brand equity, brand loyalty, etc. as dependent variables.

\section{REFERENCES}

Adjei, M., Noble, S., \& Noble, C. (2009). The influence of C2C communications in online brand communities on customer purchase behavior. Journal of the Academy of Marketing Science, 38(5), 634-653.

Aguinis, H., Gottfredson, R., \& Joo , H. (2013). "Best-Practice Recommendations for Defining, Identifying, and Handling Outliers”. Organizational Research Methods, 16(2), 270-301.

Al-Debei, M., Akroush, M., \& Ashouri, M. (2015). Consumer attitudes towards online shopping: the effects of trust, perceived benefits and perceived web quality. Internet Research, 25(5), 707-733.

Al-Gasawneh, J. A., \& Al-Adamat, A. M. (2020). The mediating role of e-word of mouth on the relationship between content marketing and green purchase intention. Management Science Letters, 10, 1701-1708.

Appel, G., Grewal, L., Hadi, R., \& Stephen, A. (2020). The future of social media in marketing. Journal of the Academy of Marketing Science, 48(1), 79-95.

Baabdullah, A., Alalwan, A., Rana, N., Kizgin, H., \& Patil, P. (2019). Consumer use of mobile banking (MBanking) in Saudi Arabia: Towards an integrated model. International Journal of Information Management, $44,38-52$.

Balakrishnan, B. K., Dahnil, M. I., \& Yi, W. J. (2012). The Impact of Social Media Marketing Medium Toward Purchase Intention and Brand Loyalty Among Generation Y. Procedia - Social and Behavioral Sciences, 177 -185 .

Beneke, J., Flynn, R., Greig, T., \& Mukaiwa, M. (2013). The influence of perceived product quality, relative price and risk on customer value and willingness to buy: a study of private label merchandise. Journal of Product \& Brand Management. 
Bennett, S., Maton, K., \& Kervin, L. (2008). The 'digital natives' debate: a critical review of the evidence. British Journal of Educational Technology, 39(5), 775-786.

Bhandari, M., \& Rodgers, S. (2018). What does the brand say? Effects of brand feedback to negative eWOM on brand trust and purchase intentions. International Journal of Advertising, 37(1), 125-141.

Brown, J., Broderick, A., \& Lee, N. (2007). Word Of Mouth Communication within Online Communities: Conceptualizing the Online Social Network. Journal of Interactive Marketing, 21(3), 2-20.

Cakmak, I. (2016). The role of brand awareness on brand image, perceived quality and effect on risk in create brand trust. New Trends and Issues Proceedings on Humanities and Social Sciences, 2(2), 177-186.

Chaffey, D., \& Ellis-Chadwick, F. (2019). Digital marketing. UK: Pearson .

Chaudhuri, A., \& Holbrook, M. (2001). The chain of effects from brand trust and brand affect to brand performance: The role of brand loyalty. Journal of Marketing, 65(2), 81-93.

Cheruiyot, T., \& Maru, L. (2013). Service quality and relative performance of public universities in East Africa. TQM Journal, 25(5), 533-546.

Chinomona, R., \& Maziriri, E. (2017). The influence of brand awareness, brand association and product quality on brand loyalty and repurchase intention: a case of male consumers for cosmetic brands in South Africa. Journal of Business and Retail Management Research, 12(1).

De Mooij, M. (2019). Consumer behavior and culture: Consequences for global marketing and advertising. SAGE Publications Limited.

Dedeoglu, B., Taheri, B., Okumus, F., \& Gannon, M. (2020). Understanding the importance that consumers attach to social media sharing (ISMS): Scale development and validation. Tourism Management, 76.

Department of Census and Statistics. (2021, 3 19). Department of Census and Statistics. Retrieved from http://www.statistics.gov.lk/Population/StaticalInformation/VitalStatistics

Dhaloki, U. M., Bagozzi, R., \& Pearo, L. K. (2004). A Social Influence Model of consumer Partcicpation in Network and Small group based Virtual Communities. International Journal of Research in Marketing, 21(3), 241-63.

Ebrahim, R. S. (2019). The Role of Trust in Understanding the Impact of Social Media Marketing on Brand Equity and Brand Loyalty. Journal of Relationship Marketing. Retrieved from https://doi.org/10.1080/15332667.2019.1705742

Elseidi, R. I., \& El-Baz, D. (2016). Electronic word of mouth effects on consumers' brand attitudes, brand image and purchase intention: an empirical study in Egypt. The Business and Management Review, 7(5), 268-276.

Etikan, I., Musa, S. A., \& Alkassim, R. S. (2016). Comparison of Convenience Sampling and Purposive Sampling. American Journal of Theoretical and Applied Statistics, 5(1), 1-4.

Evans, D., \& McKee, J. (2010). Social Media Marketing: The Next Generation of Business Engagement. Indiana: John Wiley and Sons.

Faryabi, M., Fesaghandis, K., \& Saed, M. (2015). Brand Name, Sales Promotion and Consumers‘ Online Purchase Intention for Cell-phone Brands. International Journal of Marketing Studies, 7(1), 167.

Foux, G. (2006). Consumer-generated media: Get your customers involved. Brand Strategy, 8(202), 38-39.

Hair, J., Black, W., Babin, B., \& Anderson, R. (2010). Multivariate Data Analysis . Upper Saddle River: NJ: Prentice-Hall, Inc. 
Hair, J., Sarstedt, M., Ringle, C., \& Mena, J. (2012). An assessment of the use of partial least squares structural equation modeling in marketing research. Journal of the academy of marketing science, 40(3), 414-433.

Hajli, N. (2015). Social commerce constructs and consumer's intention to buy. International Journal of Information Management, 35(2), 183-191.

Hanaysha, J. (2016, April). The Importance of Social Media Advertisements in Enhancing Brand Equity: A Study on Fast Food Restaurant Industry in Malaysia. International Journal of Innovation, Management and Technology, 7(2), 46-51.

Hayes, A. (2013). Introduction to Mediation, Moderation, and Conditional Process Analysis: A Regression-Based Approach. , . New York: The Guilford Press.

Huete-Alcocer, N. (2017). A literature review of word of mouth and electronic word of mouth: Implications for consumer behaviour. Frontiers in psychology, 8.

Irfan, A., Rasli, A., Sulaiman, Z., Sami, A., \& Qureshi, M. (2019). The Influence of Social Media on Public Value: A Systematic Review of Past Decade. Journal of Public Value and Administration Insights, 2(1), 1-6.

Jalilvand, M. R., \& Samiei, N. (2012). The effect of electronic word of mouth on brand image and purchase intention. Marketing Intelligence \& Planning, 3(4), 460-476.

Jalilvand, M. R., \& Samiei, N. (2012). The impact of electronic word of mouth on a tourism destination choice. Internet Research, 22(5), 591-612.

Johnson, S., Faraj, S., \& Kudaravalli, S. (2014). Emergence of power laws in online communities: The role of social mechanisms and preferential attachment. MIS Quarterly, 38(3), 795-808.

Jorg, M. (2017, May 03). Introducing: Generation Y. Retrieved from https://www.engarde.net/introducinggeneration-y/\#.XGE0WlwzbIU

Jung, N. Y., Kim, S., \& Kim, S. (2014). Influence of consumer attitude toward online brand community on revisit intention and brand trust. Journal of Retailing and Consumer Services, 21, 581-589.

Kaplan, A., \& Haenlein, M. (2009a). The fairyland of Second Life: About virtual social worlds and how to use them. Business Horizons, 52(6), 563-572.

Kaplan, A., \& Haenlein, M. (2009b). Consumers, companies, and virtual social worlds: A qualitative analysis of Second Life. Advances in Consumer Research, 36(1), 873-874.

Kaplan, A., \& Haenlein, M. (2010). Users of the world, unite! The challenges and opportunities of Social Media. Business Horizons, 53(1), 59-68.

Kim, E., Kim, S., \& Lee, Y. (2019). The effects of brand hearsay on brand trust and brand attitudes. Journal of Hospitality Marketing \& Management, 28(7), 765-784.

Krejcir, R. V., \& Morgan, D. W. (1970). Determining Sample Size for Research Activities. Educational and Psychological Measurement, 30, 607-610.

Kuem, J., Khansa, L., \& Kim, S. S. (2020). Prominence and Engagement: Different Mechanisms Regulating Continuance and Contribution in Online Communities. Journal of Management Information Systems, 37(1), 162-190.

Ladhari, R., \& Michaud, M. (2015). eWOM effects on hotel booking intentions, attitudes, trust, and website perceptions. nternational Journal of Hospitality Management, 46, 36-45. 
Larimo, L. F., \& Leonidou, L. (2021, p.54). Social media marketing strategy: definition, conceptualization, taxonomy, validation, and future agenda. Journal of the Academy of Marketing Science, 49(1), 51-70.

Laroche, M., Habibi, M. R., Richard, M.-O., \& Sankaranarayanan, R. (2012). The effects of social media based brand communities on brand community markers, value creation practices, brand trust and brand loyalty. Computers in Human Behavior, 28, 1755-1767.

Liao, S.-H., \& Chung, Y.-C. (2019). Interactivity, engagement, trust, purchase intention and word-of-mouth: a moderated mediation study. Int. J. Services Technology and Management, 25(2), 116-137.

Little, R., \& Rubin, D. (2002). Statistical Analysis with Missing Data. New York: John Wiley and Sons.

Main, D. (2017, May 02). Who Are the Millennials? Retrieved from https://www.livescience.com/38061millennials-generation-y.html

Manzoor, U., Baig, S. A., Hashim, M., \& Sami, A. (2020). Impact of Social Media Marketing on Consumer's Purchase Intentions: The Mediating role of Customer Trust. International Journal of Entrepreneurial Research, 3(2), $41-48$.

Mckinney, M., \& Benson, A. (2013). The value of brand trust. Journal of Brand Strategy, 2(1), 76-86.

Mehyar, H., Saeed , M., \& Baroom, H. (2020). The impact of Electronic Word of Mouth on Consumer Purchase Intention. Journal of Theoretical and Applied Information Technology, 98(2), 183-192.

Oosthuizen, D., Spowart, J., \& Meyer-Heydenrych, D. (2015). The relationship between perceived price and consumers' purchase intentions of private label wine brands. African Journal of Hospitality. Tourism and Leisure, 4(2), 1-17.

Parets, R. (2019, May 03). Marketing to Millennials: 5 Essential Tips for Reaching Them Effectively. Retrieved from https://www.fundera.com/blog/marketing-to-millennials-101

Phua, J., Jin, S., \& Kim, J. (2017). Gratifications of using Facebook, Twitter, Instagram, or Snapchatto follow brands: The moderating effect of social comparison, trust, tie strength, and network homophily on brand engagement, brand commitment, and membership intention. Telematics and Informatics, 34(1), 412-424.

Prensky, M. (2001). Digital natives, digital immigrants. On the Horizon, 9(5).

Ray, S., Kim, S. S., \& Morris, J. G. (2014). The Central Role of Engagement in Online Communities. Information Systems Research, 25(3), 528-546.

Renteria-García , J. C., Fajardo-Toro, C. H., \& Sabogal-Salamanca, M. (2021). Consumer-Generated Content as Clues for Brand Trust in the Digital Era.

Ridings, C., Gefen, D., \& Arinze, B. (2002). Some antecedents and effects of trust in virtual communities. The Journal of Strategic Information Systems, 11(3-4), 271-295.

Rockendorf, D. (2011, June 14). Continental 2011 Social Media Strategy. (P. Communication, Interviewer)

Schawbel, D. (2015, May 03). 10 New Findings About The Millennial Consumer. Retrieved from https://www.forbes.com/sites/danschawbel/2015/01/20/10-new-findings-about-the-millennialconsumer/\#3d376bf06c8f

Sparks, B., \& Browning, V. (2011). The impact of online reviews on hotel booking intentions and perception of trust. Tourism Management, 32(6), 1310-1323.

Tatar, S., \& Eren-Erdoğmuş, I. (2016). he effect of social media marketing on brand trust and brand loyalty for hotels. Information Technology \& Tourism, 16(3), 249-263. 
Thompson, R. (2018, May 03). The 'ennial tribes: Understanding Generation Y and Generation Z South Africans . Retrieved from https://www.bizcommunity.com/Article/196/19/176153.html

Ulusu, Y., Erdem, Ş., \& Durmuş, B. (2016). Influence of Social Media Based Brand Communities on Brand Trust. European Journal of Business and Management, 8(35), 67-74.

Werenowska, A., \& Rzepka, M. (2020). The Role of Social Media in Generation Y Travel Decision-Making Process (Case Study in Poland). Information, 11(396).

Wu, C. (2015). A Study on Consumers' Attitude Towards Brand Image, Athletes' Endorsement and Purchase Intention. International Journal of Organizational Innovation, 8(2).

Xia, L., \& Bechwati, N. (2008). Word of mouth: The role of cognitive personalization in online consumer reviews. Journal of Interactive Advertising, 9(1), 108-128.

Zhu, F., \& Zhang, X. (2010). Impact of Online Consumer Reviews on Sales: The Moderating Role of Product and Consumer Characteristics. Journal of Marketing, 74(2), 133-148. 